\title{
SELF LEARNING ITINERARY AS A TOOL TO IMPROVE EFFECTIVE COMMUNICATION. A QUALITATIVE ANALYSIS OF A PILOT EXPERIENCE
}

\author{
Maria del Carmen Bas ${ }^{1}$, María Jesús Lerma-García ${ }^{2}$, Nuria Matarredona- \\ Desantes $^{3}$, Raúl Oltra-Badenes ${ }^{4}$, Édgar Pérez-Esteve ${ }^{2}$, Joan Albert Silvestre- \\ Cerdà $^{5}$ \\ ${ }^{1}$ Departamento de Matemáticas para la Economía y Empresa, Universitat de València \\ (SPAIN) \\ ${ }^{2}$ Departamento de Tecnología de Alimentos. Universitat Politècnica de València (SPAIN) \\ ${ }^{3}$ Departamento de Composición Arquitectónica, Universitat Politècnica de València (SPAIN) \\ ${ }^{4}$ Departamento de Organización de Empresas, Universitat Politècnica de València (SPAIN) \\ ${ }^{5}$ Departamento de Sistemas de Información y Computación, Universitat Politècnica de \\ València (SPAIN)
}

\begin{abstract}
PIMECOE is an Innovation and Educational Improvement Project that aims to work on the student outcome "Effective Communication". Its main objective is to design a methodology that promotes the autonomous improvement of oral communication skills. In order to do so, students can assess their initial level of proficiency of oral communication through the self-diagnosis tools proposed. Once weaknesses and strengths have been detected, they are encouraged to enrol a suggested selfformative itinerary which includes learning activities that may improve their mastery of this student outcome.

As part of the design process of this PIMECOE methodology, a preliminary test has been carried out with students of the subject Introduction to Architecture (Fundaments of Architecture Degree) during the first semester of the 2017/2018 academic year. This experimental implementation, called IARexp, aims to evaluate the success of the methodology and to get feedback from the students that will be thoroughly analysed in order to develop an upgraded ulterior version.

The present paper firstly presents an introduction to the PIMECOE methodology (context, objectives and specific tools associated). Secondly, the academic context for the IARexp and the chronogram for its implementation is set. Finally, the quantitative and qualitative analysis carried out from the results obtained so far will be exposed.
\end{abstract}

Keywords: Effective communication, oral communication, student outcomes, self-diagnosis tools, selftraining.

\section{INTRODUCTION}

In recent years, institutions of higher education have experienced various changes conditioned by the demands of today's society. The adaptation of the degree titles to the European Higher Education Area is one of the unavoidable factors that have led to a change in the application of teaching methodologies, and a need to adapt and make flexible the educational offer to the current reality. In particular, the inclusion of student outcomes in curricula has become very important for both the University and the business world. There is a consensus between University and business environment on the need for future employees to master certain skills for their professional development. For the student, it is very important to acquire and accredit their mastery level in different outcomes. On the other hand, for the employer it is very important to know the mastery level of the student outcome acquired by the graduates.

Accordingly, the UPV (Universitat Politècnica de València) has included in its strategy the evaluation of two kinds of student outcomes: specific and generic. In this way, the new undergraduate and postgraduate degrees explicitly incorporate the requirement that students must be trained in certain skills, and assessed according to the corresponding domain level of the outcome. 
As in [1], generic student outcomes are "those that are key and transferable in relation to a wide variety of personal, social, academic and work contexts throughout life. In this sense, they constitute a fundamental part of the professional profile and the formative profile of all or most of the degrees. These are student outcomes that include a set of cognitive and meta-cognitive abilities, instrumental and attitudinal knowledge of great value for the knowledge society".

Given that generic student outcomes are a complex know-how, it is necessary to determine specific learning outcomes. Therefore, it is necessary to resort to methodological strategies that favour a change of roles. A 'traditional' methodology based on lectures and problems that the teacher solves in the classroom turns out to be inappropriate under this framework. Even laboratory practices must change their approach to achieve new objectives and ensure that students acquire a set of skills that, in general, are not previously taken into account or evaluated, such as the ability to work in groups, the ability to make oral presentations, etc. [2]. To master these student outcomes it is necessary to carry out training actions. These actions must be based on active methodologies for the learning of outcomes and methods based on student participation that generate a deeper, meaningful and lasting learning [3].

In this context, the UPV has identified thirteen generic student outcomes that students have to develop when studying their degrees. One of these UPV's generic student outcomes is "effective communication", in which there is a greater consensus regarding the importance it has for future graduates. According to the institutional project developed by the UPV, it means "the ability to transmit knowledge and arguments clearly, rigorously and convincingly, both orally and in writing, using the resources properly and adapting to the characteristics of the situation and audience". It is important to differentiate the two dimensions within this student outcome: oral and written communication [4].

The mastery of the effective communication student outcome implies the effectiveness in the communication of ideas, knowledge and feelings through speech and writing in group activities or public presentations and speeches, among others [5]. Students who have accessed to the University have already acquired a certain amount of instrumental knowledge of techniques and strategies for a good communication, but the University must assure that further development of this student outcome is carried out, taking into account its important academic, professional and personal implications. From a strictly academic point of view, verbal and written interactions are the key to the teaching-learning process, since they facilitate collaborative activity, make possible the internalization of knowledge, and are fundamental to achieve a good academic performance. In professional life, it is essential to know how to transmit ideas, knowledge and feelings in a precise way to obtain greater efficiency. Finally, from a personal perspective, being able to talk in public safely and without nervousness, as well as the ease of expressing oneself in writing without difficulties, entails an increase in personal security and reinforces self-esteem [6].

It is important to bear in mind that students face the development of this student outcome with very different initial mastery levels. This is due to the different innate abilities and different acquisition rates of this outcome. In addition, this disparity can be accentuated if the students are enrolled in different degrees and cycles. Therefore, different problems arise in terms of the acquisition of this generic student outcome. The following questions arise when working the "effective communication" student outcome:

- Which is the initial mastery level of this generic student outcome of the students from different degrees and cycles?

- How is this student outcome worked in class?

- What evaluation / diagnostic tools are used to analyse the mastery level of the student outcome?

- There exist support and improvement tools that guide the student to the acquisition / improvement of the student outcome?

- What training activities should be proposed to improve the mastery level of the student outcome?

\section{AN INTRODUCTION TO PIMECOE}

PIMECOE is a methodology designed by the PIMECOE team in order to let students improve autonomously their mastery in oral expression. The student has three phases. 


\subsection{Phase 1. Initial communication act + Self-diagnosis test}

The first phase of the methodology corresponds to the detection of the initial mastery level of the students. For this purpose, the teacher proposes an initial oral communication act that allows them to test their initial level and evaluate, using the rubric of the evaluation designed by the UPV (Figure 3), the mastery of the student outcome indicators. The feedback allows the students to determine the strengths and weaknesses in relation to the basic and advanced indicators that define each mastery level of the student outcome. Then, the student must perform the self-diagnostic test designed within the framework of the PIMECOE project using the personal experience of the initial communicative act. The main purpose of the self-diagnostic test of the generic student outcome Effective Oral Communication is none other than to guide and help the student in improving their skills to achieve effective oral communication from a series of measurable indicators provided by the test itself.

\subsection{Phase 2. Execution of the self-formative itinerary}

The second phase corresponds to the execution of the self-formative itinerary, consisting of a working document that specifies, based on the answers provided by the students in the self-diagnostic test, the set of activities that the student must work to improve their mastery level.

\subsection{Phase 3. Act of final oral communication for the identification of improvements and permanence of errors.}

In the last phase of the proposed self-formative methodology, an oral communication act is proposed, which may be the same or similar to the initial one. The objective of this final act is to evaluate the students again by means of the indicators of the university's rubric and to identify the improvements of the oral communication and the persistent errors or weak points that students have not been able to improve.

The self-diagnosis test and the self-formative itinerary could be found in the on-line web of the PIMECOE project [7].

\section{METHODOLOGY}

\subsection{Objective}

The objective of the present pilot experience is to experimentally implement the self-learning process proposed by the PIMECOE project in order to get feedback. The information obtained will be thoroughly analysed so as to design an ulterior version of the process.

\subsection{Academic context for the pilot experience}

The "Introduction to Architecture Experience" (IARexp) is the name that has been used to refer to this first pilot trial of the PIMECOE methodology. Its name derives from the target group selected: students enrolled in "Introduction to Architecture" (IAR) willing to get involved. This means that participation is not compulsory but encouraged.

IAR is an introductory course that is developed during the first semester of the "Grade in Fundaments of Architecture" (September to January). As a matter of fact, it has to be highlighted that students are not yet familiar with the University system. Its main objective is to reflect about the meaning of architecture and the role that architects should play in our society as well as to approach theoretical concepts that will allow students to learn from case studies analysis.

The experimental practice has been carried out concurrently in two different groups. Group $C$ is composed by 45 students whose vehicular language is Valencian. Conversely, group D, formed by 60 students which communicates in Spanish. 


\subsection{Pilot experience timeline}

The itinerary has been designed so that students can monitor their own progress during the semester.

During the first weeks of the course, students are invited to think about their personal disposition towards communication.

\subsubsection{Opinions on architecture}

This task is part of the first unit of the course devoted to reflect about what is architecture from different perspectives. Personal reflection and collective debate are followed by the development of the task called "Opinions in architecture" where students are invited to learn from other prestigious architects and their concept of architecture.

In order to do so, students need to find a definition of architecture that looks somehow appealing to them. Once selected, they need to delve into the figure of its author and the architecture that he or she built. Afterwards, they will choose one of the architect's operas as a case of study to analyse. Finally, they will try to discern if there is any connection between the concept of architecture the author stated and his or her built work.

As a matter of fact, the main outcome pursued by this activity is not only to broaden their concept of architecture but to become familiar with architects they probably did not know yet and the architecture they built. This kind of project also aims to help them develop their critical sense while they learn how to analyse architecture.

As every project is developed individually, it is very important that results are shared with the rest of their colleagues so they can all learn from the others. Consequently, oral exposition sessions are held to let students talk about their case of study and how it broadened their idea of architecture.

These presentations follow the PechaKucha system. This format, established in 2003 by Kein Dytham Architecture [8], consists of 20 images that advance automatically every 20 seconds as the presenter talks along them. In this case, the format is adapted to 10 images, so every presentation lasts 3 minutes and 20 seconds.

\subsubsection{Feedback}

Students are invited to peer evaluate the oral communication student outcome of their colleagues by using a rubric designed for that purpose. Five indicators with their corresponding mastery level (from $A$ excellent to $D$ non achieved) are set:

- 11: Transmits relevant information and knows how to answer the questions that are asked

- 12: The exhibitions are structured in a coherent way

- 13: Language is used with grammatical correctness: semantic, syntactic and orthographic

- 14: The speaker non-verbal communication transmits tranquillity

- 15: Means of support are used in a relevant way

A rubric checklist with two additional boxes, included to qualitatively evaluate both the oral exposition and the content of the task, are given along the rubric.

\begin{tabular}{|c|c|c|c|}
\hline \multicolumn{4}{|l|}{ ESTUDIANT: } \\
\hline $1 D C B A A$ & $3 \mathrm{D}$ & 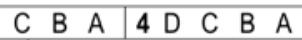 & 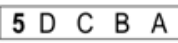 \\
\hline Comentaris a la exposició: & & Comentaris al treball: & \\
\hline
\end{tabular}

Fig 1. Verification checklist. 


\subsubsection{Self-diagnosis}

In order to make any progress, students need to be aware of their initial mastery level of the oral student outcome. This is established trough two systems. On one hand, students can performed the "self-diagnosis test" created by the PIMECOE project. Its results will make it evident their weak and strong areas. On the other hand, students receive a complete report elaborated by the PIMECOE team with their colleagues and professor feedback.

As a matter of fact, students know in what possible ways they can improve the way they orally express their ideas.

\subsubsection{Final Task}

This task is part of the last unit and it is designed as a final task that recovers all the concepts developed during the course. "The house", as it is called, consists on the detailed analysis of a case of a study house using the skills acquired.

Also in this case, students present their task to the rest of the class as they have done previously in the first oral exposition. Moreover, before the oral exposition, each student evaluated the presentation of two colleagues using a paired peer-review process implemented in a tool offered by the educational platform of the UPV [9].

This means that students will approach the case studies in 3 different levels: very deep, the one they have developed; quite deep, the two cases they had to asses using the paired peer-review process and deep, the ones they assess during the oral expositions.

Assessment of the oral expositions is done following the same system explained for Task 1.

\section{RESULTS}

This section shows the results obtained from the implementation of the self-formative methodology for the improvement of the mastery of the Effective Oral Communication student outcome, proposed in the PIMECOE project, in the pilot experience in the Grade in Fundaments of Architecture. Figure 2 shows an example of the oral exposure of a student.

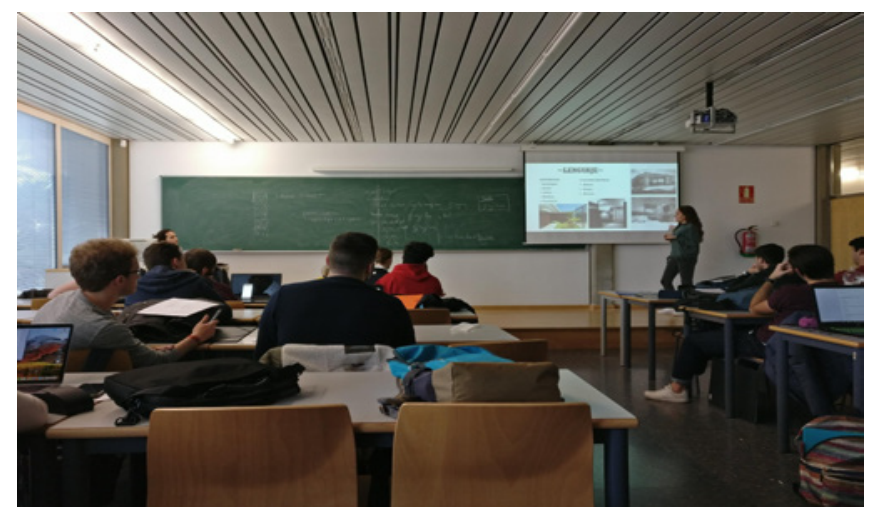

Fig 2. Student presenting her project.

The following report is the feedback that is given to the students after performing oral presentations 1 and 2 . The report includes a quantitative and a qualitative part. The quantitative part is based on the results of the rubric obtained in the evaluation of oral communication acts at the beginning (Task 1) and at the end (Task 2) of the applied methodology. In this way, the results allow a comparison between before and after the application of the proposed methodology (pre-test and post-test) and observe improvements in the development of the outcome worked. In this part is presented the percentage of $A, B, C$ and $D$ evaluated in each indicator. Additionally, the qualitative part includes comments of the evaluators considering the exposition of the student.

For instance, the report of figure 3 shows the result of "Student 1 " after the oral presentation of the Task 1. Results show that the majority of the evaluators think that "Student 1" has a good level in indicators 1,2,3 and 5. The mastery level in indicator 3 is lower since the $51.85 \%$ of the evaluators think that the level is in progress. 


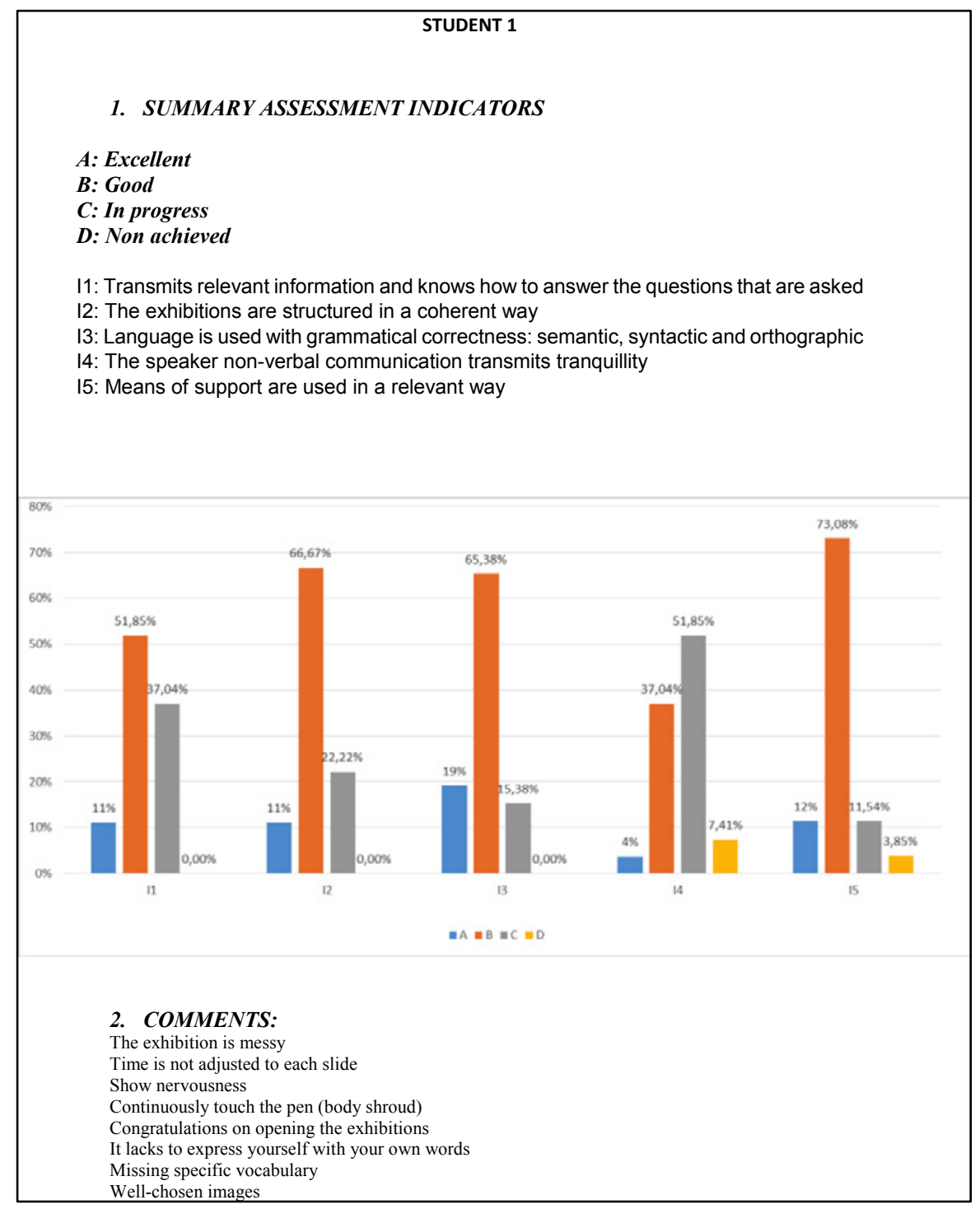

Fig 3. Report with the feedback of the evaluation.

After analysing this first report, the students have the task of improving their weaknesses through the self-diagnostic test provided by the PIMECOE methodology. Throughout the course, the students carry out the activities recommended by the self-diagnostic test for the improvement of the mastery level of the oral student outcome. The students will have to put into practice again the oral outcome in the development of the oral presentation of the Task 2. To finish the methodology, the students receive another report of the same type that allows them to analyse the improvements with respect to the previous report.

We had a sample of 46 students in the pre-test and 36 students in the post-test of which 30 have done both phases. Figure 4 shows the general results of the percentage of the different mastery levels obtained for all the indicators evaluated in the rubric in the pre-test (46 students) and post-test (36 students). The results show that the percentage of "A: excellent level" and "B: good level" has increased in the post-test, while the levels "C: in progress" and "D: non achieved" have decreased after implementing the self-formative methodology. 


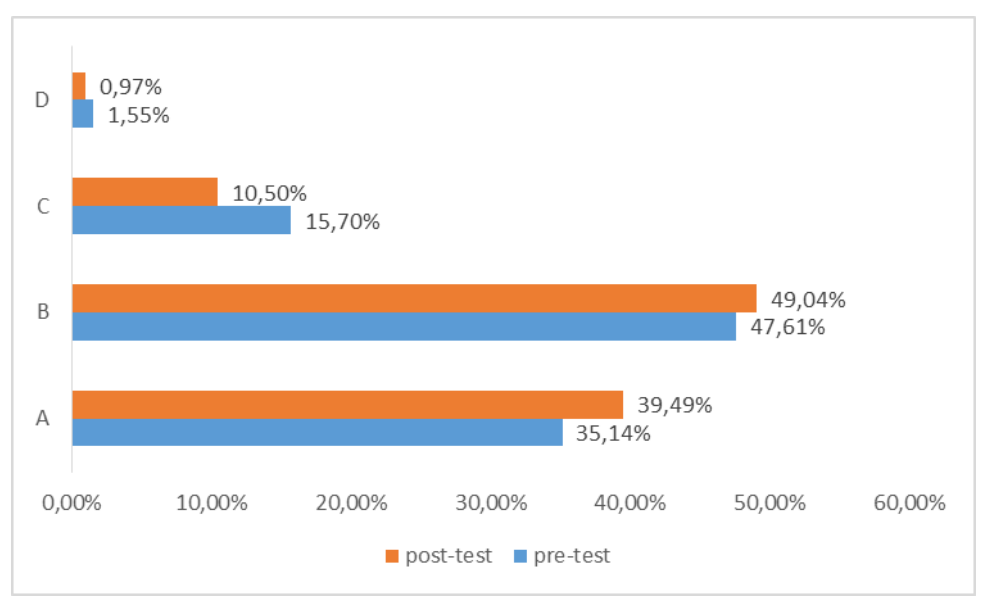

Fig 4. Results of the Pre and Post-test.

\section{CONCLUSIONS}

The development of the generic student outcome "Effective Communication" and, in particular, its oral dimension, is very important within the University environment, since the student must express their doubts, their opinions and even make oral presentations throughout their academic career. In addition, this student outcome is highly valued and required in the business field so it is very important to acquire and work it at University. However, due to the limited time that teachers have to work on generic student outcomes in class, their learning is not usually deepened. The self-formative methodology proposed in this study allows the student to work to improve the acquisition of the student outcome, measuring the initial mastery level and offering an auto-formative itinerary for its improvement. This methodology does not require a lot of class time, since it is an autonomous learning on the part of the student but at the same time supervised by the teacher to comply with a learning contract established by both parties. The quantitative results of the implementation of the selfformative methodology in a pilot experience formed by first-grade students shows improvements in the acquisition of the student outcome. We believe that it is a very useful methodology, applicable to any degree and master of the University and extendible to the development of the same for the mastery of other generic student outcomes.

\section{ACKNOWLEDGEMENTS}

The present research has been developed within the research project called "Autodiagnóstico del nivel de dominio inicial de la competencia transversal "Comunicación Efectiva" y su mejora a través de un itinerario autoformativo" (Ref.: PIME/2017/B/025-14) funded by the Vice-Rectorate for Studies, Quality and Acreditation at Universitat Politècnica de València. The PIMECOE project members would also like to express their gratitude to the students that have been part of this study.

\section{REFERENCES}

[1] ICE - INSTITUTO DE CIENCIAS DE LA EDUCACIÓN. UNIVERSITAT POLITĖCNICA DE VALĖNCIA (2015) Proyecto Competencias Transversales UPV <http ://www.upv.es/entidades/ ICE/info/U0724624.pdf> [Consulta: 27 de marzo de 2017].

[2] OLTRA-BADENES, R. y GIL-GÓMEZ, H. (2015) "Técnicas de aprendizaje cooperativo: aplicación de metodologías activas en la asignatura de Recursos Humanos en Empresas Industriales". En: 3rd International Conference on Innovation, Documentation and Teaching Technologies (INNODOCT/15). Valencia: Open Innovation and Coolhunting in Education. 374382.

[3] FERNÁNDEZ, A. (2006) "Metodologías activas para la formación en competencias" en Educatio Siglo XXI, vol. 24, p. 35-56.

[4] UNIVERSITAT POLITĖCNICA DE VALĖNCIA (2012) Competencias transversales. Blog <http://www.upv.es/contenidos/COMPTRAN/info/956832normalc.html> [Consulta: 23 de abril de 2017]. 
[5] VILLA, A. y POBLETE, M. (2007) Aprendizaje Basado en Competencias. Una propuesta para la evaluación de las competencias genéricas. Bilbao: Universidad de Deusto.

[6] SAYÓS, R. (2013) "Las competencias transversales en las titulaciones de grado de la Universidad de Barcelona. Orientaciones para su desarrollo" en Cuadernos de Docencia Universitaria, vol. 27.

[7] SILVESTRE-CERDÁ, J.A., BAS, M.C., LERMA-GARCÍA, M.J., MATARREDONA-DESANTES, N., OLTRA-BADENES, R. y PÉREZ-ESTEVE, E. (2017) PIMECOE - Efective Oral Communication <https://pimecoe.wordpress.com/> [Consulta: 11 de marzo de 2018].

[8] PECHAKUCHA (2018) Metodología Pechakucha < http://www.pechakucha.org/faq> [Consulta: 14 de marzo de 2018].

[9] MATARREDONA DESANTES, N. (2017) "La evaluación por pares en el ámbito no presencial." En Sein Echaluce Lacleta. 